\title{
LONG-TERM VARIABILITY OF STRABISMUS ANGLE IN NEUROLOGICALLY IMPAIRED PREMATURE INFANTS: A 12-YEAR FOLLOW UP
}

\author{
Ena Sardelić ${ }^{1}$ and Dobrila Karlica Utrobičić ${ }^{2}$
}

\begin{abstract}
${ }^{1}$ Pediatric Resident, Department of Pediatrics, Split University Hospital Centre, Split, Croatia; ${ }^{2}$ Department of Ophthalmology, Split University Hospital Centre, Split, Croatia
\end{abstract}

\begin{abstract}
SUMMARY - The aim of this retrospective study was to determine the strabismus angle variability and rationality of surgical treatment of strabismus in prematurely born children with neurological impairment during 12-year follow up. Eleven premature infants born in 2003 were included in the study and treated with equal conservative approach from 2005 until 2016. Initial esotropia was found in seven and exotropia in four of eleven children. Changes in the strabismus angle correlated significantly with aging of the children. In children with initial esotropia, the strabismus angle became less convergent (less positive), changed the orientation and became more divergent with aging. In those with initial exotropia, the angle became less divergent (more positive), changed the orientation and became more convergent. Moreover, a significant difference in the strabismus angle was found during the 12-year follow up. Based on our results, due to the variability in strabismus angle, we did not find enough evidence for optimal timing or rationality of strabismus surgery in neurologically impaired children born prematurely.
\end{abstract}

Key words: Strabismus; Infant, premature; Developmental disabilities

\section{Introduction}

The eye and the developing visual system in preterm infants are especially vulnerable to damaging effects during pregnancy, especially those that affect the central nervous system ${ }^{1}$. Therefore, ophthalmologic problems are more often encountered in neurologically impaired preterm children, specifically those with eye motility disorders, strabismus in particular ${ }^{2,3}$. The prevalence of strabismus is considerably increased in premature infants with neurological impairment compared to normal infants ${ }^{4,5}$. This increased prevalence requires special ophthalmologic attention to infants with neurological impairment. However, those infants often tend to be excluded from the studies of strabismus treatment $t^{6-8}$. The exclusion most likely arises from

Correspondence to: Ena Sardelić, MD, Split University Hospital Centre, Spinčićeva 1, HR-21000 Split, Croatia

E-mail: ena.sardelic@gmail.com

Received March 6, 2018, accepted July 11, 2018 the conviction that neurologically impaired infants have variable angles of strabismus and poorer surgical outcomes. This is possibly due to the underlying defects in binocular function, decreased fusional capacity, and neurological problems, as well as possible abnormal global muscle tone ${ }^{6,9-12}$. Moreover, there is no consensus in the literature as to whether the guidelines for surgical treatment for strabismus are also applicable to children with neurodevelopmental delay. The latest recommendations published by the American Society of Ophthalmology, as part of the preferred practice pattern in children with strabismus, does not address premature infants with strabismus as a specific population ${ }^{13}$. However, in a guideline published by the Royal College of Ophthalmologists it is stressed that there are potential gains and risks with the management of strabismus in younger children because of the more profound degradation of visual acuity and binocular vision ${ }^{14}$. Furthermore, in infantile esotropia, controversies still exist regarding age and type of surgery, while 
in infantile exotropia constant deviation predicts poor surgical outcome in long-term follow up ${ }^{14,15}$. If ocular alignment is changing substantially over time, there is a high likelihood of poor surgical outcome ${ }^{16}$. Therefore, waiting for stability might be an option for surgical intervention ${ }^{16}$.

We investigated a case series of eleven premature neurologically impaired children with strabismus in order to assess long-term variability of ocular alignment and rationality of surgical interventions in these patients.

\section{Subjects and Methods}

Medical records of neurologically impaired premature children with strabismus born in 2003, presented to the Outpatient Orthopleoptic Clinic, Department of Ophthalmology, Split University Hospital Centre, were reviewed retrospectively. Patients were identified from a strabismus database, covering a 12-year period. Patient charts were examined for gestational age, neurological impairment, strabismus angle, refractive anomaly and nystagmus. Data on the type and size of strabismic deviation were collected and statistically analyzed. The measurement of horizontal heterophoria at near (with correction of refractive errors) was done in 2005 using Maddox wing and the prism cover test, whereas from 2006 until 2016 a synoptophore was used (Synoptophore, Synoptometer Oculus Optikgerate $\mathrm{GmbH}$, Wetzlar, Germany) ${ }^{17}$. Cycloplegic retinoscopy was performed at least annually to measure refractive errors ${ }^{17}$. Visual acuity was assessed with and without correction with optotypes (standard letter or symbol acuity test) from standard distance ${ }^{17,18}$. Only the conservative approach to strabismus treatment was applied, including occlusion therapy or eye patching, spectacles and eye exercises of the squint eye. No surgical procedure was performed throughout the study period. Patients were also regularly examined by neuropediatricians and physical rehabilitation was performed.

The study was approved by the Thesis Committee of the School of Medicine, University of Split. Statistical analysis was performed by use of the SPSS 20.0 program (IBM, Armonk, NY, USA). Descriptive statistics, Spearman correlation analysis and Friedman analysis of variance were used. Statistical significance was set at $\mathrm{p}<0.05$.

\section{Results}

The study included eleven premature infants born in 2003, three females and eight males. Two subjects were born at 30, two at 31, four at 32, two at 33 and one at 34 weeks of pregnancy. In the present study, neurological impairment was defined as the presence of diagnosis including intraventricular hemorrhage (IVH) and/or periventricular leukomalacia (PVL) and/or obvious neurological sequels.

The first ophthalmologic measurements were done in 2005, at age two. Primary esotropia (ET) and hypermetropia were found in seven out of eleven (63.6\%) children, whereas exotropia (XT) with concomitant myopia was present in the remaining four $(36.4 \%)$ children. The size of the strabismus angle at the first measurement varied substantially with a median of 18 degrees (range -30 to 30 degrees). Out of all study infants, four (36.4\%) had nystagmus, including three with esotropia and one with exotropia. Seven out of eleven children had unilateral amblyopia, whereas the remaining four had bilateral amblyopia. Changes in refraction errors and visual acuity were not analyzed in this study.

During the 12 study years, a statistically significant negative correlation was found between the measured angle of strabismus and patient age in esotropic children (Table 1). In four out of seven esotropic children, the angle of deviation became less convergent (more negative) and changed to exotropia (becoming mathematically more negative but in fact the angle of strabismus became less convergent and then more divergent). The remaining three patients kept esotropic deviation, although a significant negative correlation was also found, meaning that the angle became less positive, less convergent (Fig. 1).

In exotropic children who presented with myopia at the beginning of the study, a significant and positive correlation of strabismus angle and patient age was found (Table 2). In fact, the angle of deviation became less divergent (more positive) and when the deviation changed direction it became ever more convergent (more positive) (Fig. 2).

In reality, during childhood, the angle of deviation decreased in both groups of strabismus patients (becoming less convergent or less divergent), the direction of deviation changed in the majority of them, and finally the angle of deviation started to increase over time. 
Table 1. Strabismus angle in esotropic children with absolute change in strabismus angle after 12-year follow up and Spearman correlation coefficient

\begin{tabular}{|l|l|l|l|l|l|l|}
\hline Case No. & Gender & Birth at week & $\begin{array}{l}\text { Strabismus angle } \\
\text { in 2005 (degrees) }\end{array}$ & $\begin{array}{l}\text { Strabismus angle } \\
\text { in 2016 (degrees) }\end{array}$ & $\begin{array}{l}\text { Absolute change } \\
\text { (degrees) }\end{array}$ & Rho (p) \\
\hline 1 & Male & 32 & 30 & -18 & 48 & $-0.99(<0.001)$ \\
2 & Male & 34 & 14 & -10 & 24 & $-0.86(<0.001)$ \\
5 & Male & 32 & 21 & -14 & 35 & $-0.99(<0.001)$ \\
6 & Male & 31 & 28 & -11 & 39 & $-0.99(<0.001)$ \\
7 & Female & 32 & 18 & 12 & 3 & $-0.73(0.007)$ \\
9 & Male & 31 & 26 & 9 & 21 & $-0.91(<0.001)$ \\
10 & Female & 30 & 30 & & & $-0.99(<0.001)$ \\
\hline
\end{tabular}



Fig. 1. Changes in strabismus angle during 12-year follow up (2005-2016; children's chronological age 2-13) in children initially presented with esotropia and hypermetropia.

In esotropic children, changes in the medians of strabismus angles throughout the study period were significant $(\chi=68 ; \mathrm{p}<0.001)$ (Table 3$)$. The significance was mostly due to differences in the strabismus angles recorded at the age of two compared to those from the age of six to the age of thirteen, then at the age of three with those from the age of seven to the age of thirteen, and from the age of four with those from the age of eight to the age of thirteen. At the age of five and six, significant changes were only observed on comparing the values recorded from the age of ten to the age of thirteen. At the age of seven, significant changes were recorded on comparing the values observed from the age of eleven until the age of thirteen. Comparisons of the values between the age of two to the age of five and the age of eight to the age of thirteen did not yield significant changes in medians of the strabismus angles. Almost the same results were observed in exotropic children. Changes in medians of the strabismus angles during the 12 -year period were significant $(\chi=38.6 ; p<0.001)$ and were mostly observed, as in esotropic children, when comparisons were made at least with several years apart. Medians of the strabismus angles recorded from the age of two until the age of 
Table 2. Strabismus angle in exotropic children with absolute change in strabismus angle after 12-year follow up and Spearman correlation coefficient

\begin{tabular}{|l|l|l|l|l|l|l|}
\hline Case No. & Gender & Birth at week & $\begin{array}{l}\text { Strabismus angle } \\
\text { in 2005 (degrees) }\end{array}$ & $\begin{array}{l}\text { Strabismus angle } \\
\text { in 2016 (degrees) }\end{array}$ & $\begin{array}{l}\text { Absolute change } \\
\text { (degrees) }\end{array}$ & Rho (p) \\
\hline 3 & Male & 33 & -7 & 10 & 17 & $0.82(0.001)$ \\
4 & Female & 33 & -20 & 15 & 35 & $0.98(<0.001)$ \\
8 & Male & 32 & -20 & 16 & 36 & $0.79(0.002)$ \\
11 & Male & 30 & -30 & 14 & 44 & $0.98(<0.001)$ \\
\hline
\end{tabular}

Strabismus angle

(degrees)

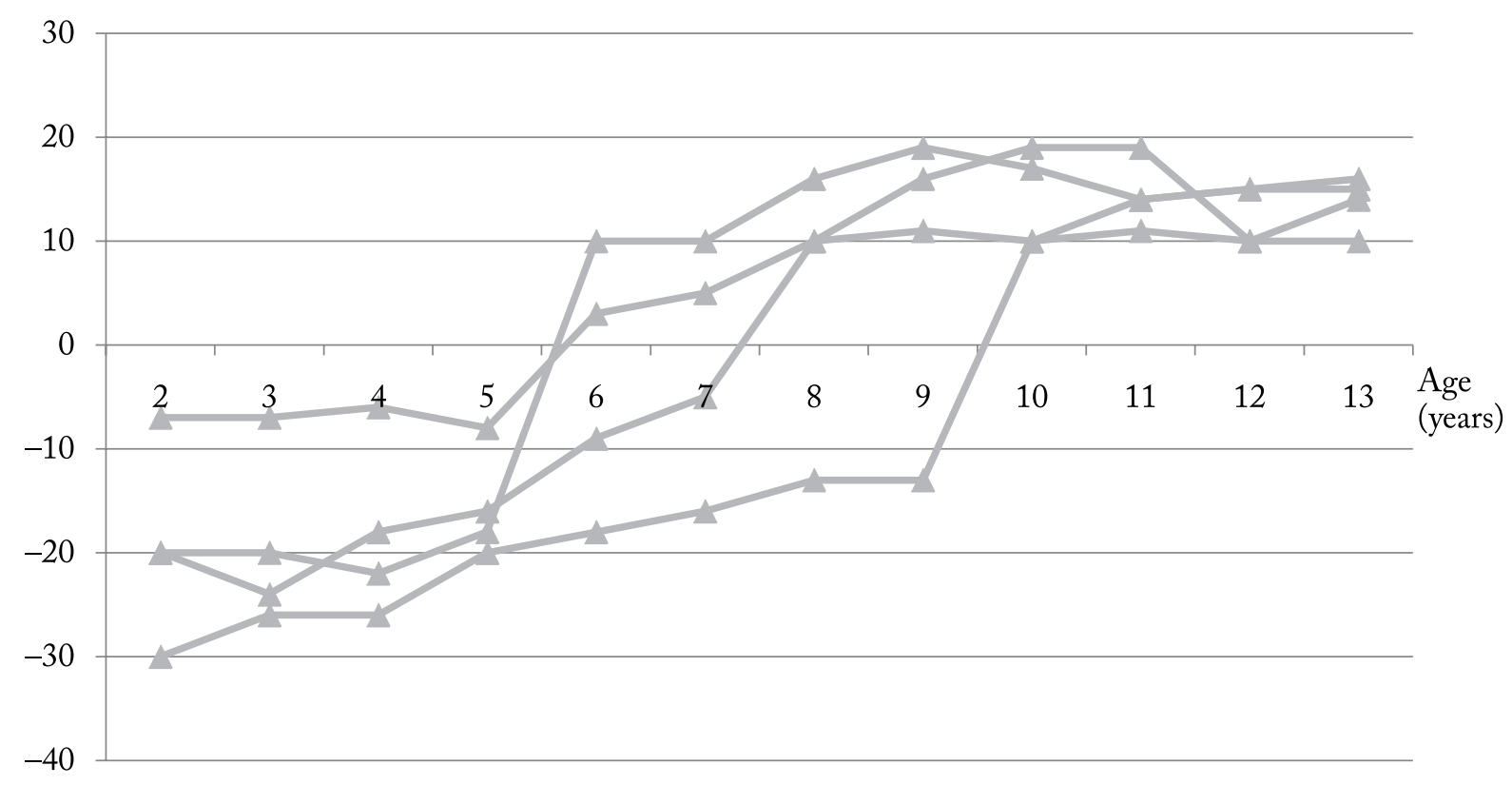

Fig. 2. Changes in strabismus angle during 12-year follow up (2005-2016; children's chronological age 2-13) in children initially presented with exotropia and myopia.

five in exotropic children were statistically different from those recorded from the age of eleven until the age of thirteen. Those recorded at the age of six were significantly different from those observed only at the age of thirteen. As in esotropic children, no significant changes in medians were observed on comparisons from the age of two to five and from the age of seven to thirteen.

Changes in deviation directions, i.e. transition from esotropia to exotropia and vice versa, were mostly recorded after four or five years of follow up (at the age of six or seven), as shown in Table 4. No change in the deviation angle was seen in three out of seven esotropic children, but a change in the strabismus angle to esotropic was recorded in all of the exotropic children.

\section{Discussion}

Strabismus is a common condition in childhood, affecting $2 \%-4 \%$ of the population younger than six years ${ }^{19-21}$, with an increased prevalence in premature infants and neurodevelopmental disorders ${ }^{2,22-24}$. Correction of strabismus and achievement of binocular vision have direct impact on the child's motor, social and psychological development ${ }^{25}$. This achievement, however, could be hindered by neurological impairment. The main aims of ophthalmologic management are to further diagnose and classify strabismus, monitor visual development and refractive errors, treat amblyopia and manage strabismus to obtain, maintain or restore binocular single vision where such a potential is pres- 
Table 3. Changes in medians of strabismus angle (with minimal and maximal values) during 12-year follow up

\begin{tabular}{|l|l|l|l|l|}
\hline $\begin{array}{l}\text { Children's age } \\
\text { (years) }\end{array}$ & $\begin{array}{l}\text { Esotropic children: median (min, max) } \\
\text { of strabismus angle (degrees) }\end{array}$ & $\mathrm{p}^{*}$ & $\begin{array}{l}\text { Exotropic children: median (min, max) } \\
\text { of strabismus angle (degrees) }\end{array}$ & $\mathrm{p}^{*}$ \\
\hline 2 & $26(14,30)$ & $<0.001$ & $-20(-30,-7)$ & $<0.001$ \\
3 & $20(10,28)$ & $-22(-26,-7)$ & \\
4 & $20(6,28)$ & $-18(-26,-6)$ & \\
5 & $16(8,22)$ & $-17(-20,-8)$ & \\
6 & $14(5,20)$ & $0(-18,10)$ & \\
7 & $10(-3,19)$ & $10(-13,16)$ & \\
8 & $9(-10,16)$ & $13.5(-13,19)$ & \\
9 & $6(-10,19)$ & $13.5(10,19)$ & \\
10 & $-7(-12,15)$ & $14(11,19)$ & \\
11 & $-7(-14,14)$ & $12.5(10,15)$ & \\
12 & $-8(-15,13)$ & & \\
13 & $-10(-18,15)$ & & \\
\hline
\end{tabular}

${ }^{*}$ Friedman analysis of variance

Table 4. Children's age when smallest strabismus angle was recorded and direction of deviation changed

\begin{tabular}{|l|l|l|l|}
\hline Case No. & $\begin{array}{l}\text { Initial } \\
\text { strabismus }\end{array}$ & $\begin{array}{l}\text { Child's age in } \\
\text { years (smallest } \\
\text { angle in degrees, } \\
\text { strabismus type) }\end{array}$ & $\begin{array}{l}\text { Direction } \\
\text { change } \\
\text { (child's age } \\
\text { in years) }\end{array}$ \\
\hline 1 & Esotropia & $7(-3$, exotropia) & 7 \\
2 & Esotropia & $7(-3$, exotropia) & 7 \\
5 & Esotropia & $7(5$, esotropia) & 8 \\
6 & Esotropia & $9(6$, esotropia) & 10 \\
3 & Exotropia & $6(3$, esotropia) & 6 \\
4 & Exotropia & $7(5$, esotropia) & 7 \\
8 & Exotropia & $6(10$, esotropia) & 6 \\
11 & Exotropia & $10(10$, esotropia) & 10 \\
\hline
\end{tabular}

ent $^{14}$. Strabismus in childhood could be treated conservatively or surgically. Optimal timing for surgical correction in those children is not clear. It seems that in subjects with unstable ocular alignment, waiting for stability might result in better motor alignment after surgery and better long-term sensory outcomes ${ }^{16,26,27}$. Therefore, the aim of this study was to assess if children born prematurely with neurologic impairment could achieve stability in strabismus angle during childhood and the rationality of surgical approach in those children if stability was not achieved.

Eleven premature neurologically impaired children born in 2003 at gestational age 30-34 weeks were studied until 2016, i.e. until chronological age of 13 years. Seven out of eleven children presented initially with esotropia, which is reported as more frequent than exotropia in children with neurological disorders $^{28-31}$. In all patients, a statistically significant correlation (with Spearman correlation coefficient higher than 0.7) was found between the measured angle of deviation and the year of follow up, i.e. the age of children. This correlation was statistically negative in children with esotropia, and statistically positive in those with exotropia. However, in both groups of patients, the angle of strabismus decreased up to the age of six or seven; after that, in the majority of patients, the eye deviation changed direction, and then the angle of strabismus gradually increased up to the age of twelve. In eight out of eleven children, the deviation changed direction, i.e. in four out of seven from esotropia to exotropia, and vice versa in all exotropic children. These changes are frequently seen, especially in neurologically impaired children regardless of the treatment approach and are often the reason for repeated surgical corrections $^{32,33}$. In neurologically impaired children treated conservatively, Sekeroglu et al. found a change in strabismus after only three years of follow up. In that study, five out of thirteen children with initial esotropia changed to exotropia ${ }^{28}$. Erkillä et al. followed up children with cerebral palsy and in approximately onethird of them, strabismus changed from esotropia to exotropia ${ }^{34}$. Habot-Wilner et al. conducted five-year follow up in 24 children with strabismus and neurode- 
velopmental disorders, age range from 10 months to 10 years. All of them were treated surgically but unsatisfactory results were found in the majority of them (15 out of 24 ), with only $38 \%$ success rate, whereas reoperation was required in eight children ${ }^{35}$. In an earlier report by the same authors, the success of surgical correction was $56 \%$, but the children were followed up for only 17 months ${ }^{32}$. In our study, a significant difference between medians of the strabismus angle was only found when comparisons were made after at least a four-year period. In other words, if the recorded angles were compared within a shorter time frame, no significant changes would be observed.

This instability in strabismus could be a direct consequence of morphological changes during development of binocular vision, such as the growth of the eye, retinal growth, development and organization of the myriad of paths between the eye and the cortex, together with functional changes in cortical neurons, including those in the optical cortex ${ }^{37}$. All these events take place during the critical period lasting until the age of six or seven, and then slightly decreasing until the age of $\operatorname{ten}^{37}$.

It is very difficult to predict if the described changes would have happened even after surgical correction, but with the presumption that changes in maturation at any sensomotor level of visual perception are present in those children, the same instability is to be expected ${ }^{38}$.

It should be stressed that the number of children studied was too small to extrapolate our findings to the population of children born prematurely with strabismus and neurological impairment but literature data on these children are too scarce and almost without exception presented only with short-term follow up results.

\section{Conclusion}

In neurologically impaired children with strabismus, a statistically significant variability in strabismus angle was found during the 12-year follow up. Because of this variability in the strabismus angle, optimal timing or rationality for strabismus surgery could not be determined. We concluded that in children born prematurely with strabismus and neurological impairment, only long-term follow up provided an insight into changes in eye alignment during childhood. Since monitoring and assessment of visual acuity, refractive errors and amblyopia significantly influence the choice of therapy and monitoring success of treatment of strabismus, these parameters should be taken into consideration in future studies. Further, long-term studies with a larger and more homogeneous population sample of children born prematurely with strabismus and neurological disorders could better clarify the problem of strabismus treatment in this group of children.

\section{Acknowledgment}

We thank V. Čapkun for assistance in statistical analysis.

\section{References}

1. Jacobson LK, Dutton GN. Periventricular leukomalacia: an important cause of visual and ocular motility dysfunction in children. Surv Ophthalmol. 2000;45(1):1-13. PMID: 10946078

2. Holmstrom G, el Azazi M, Kugelberg U. Ophthalmological follow up of preterm infants: a population based, prospective study of visual acuity and strabismus. Br J Ophthalmol. 1999; 83:143-50. PMID: 10396188

3. Pott JW, Van Hof-van Duin J, Heerseema DJ, Fetter WP, Schreuder AM, Verloove- Vanhorick SP. Strabismus in very low birth weight and/or very preterm children: discrepancy between age of onset and start of treatment. Eur J Paediatr. 1995;154:225-9. PMID: 7758523

4. Sandfeld Nielsen L, Jensen H, Skov L. Risk factors of ophthalmic disorders in children with developmental delay. Acta Ophthalmol. 2008;86(8):877-81. PMID: 18577186

5. Marlow N, Wolke D, Bracewell MA, Samara M. Neurologic and developmental disability at six years of age after extremely preterm birth. N Engl J Med. 2005;352:9-19. PMID: 15635108, DOI:10.1167/iovs.10-6906

6. Biglan AW, Davis JS, Cheng KP. Infantile exotropia. J Pediatr Ophthalmol Strabismus. 1996;33:79-84. PMID: 8965243

7. Hunter DG, Kelly JB, Buffenn AN. Long-term motor and sensory outcomes of uncomplicated infantile esotropia. J AAPOS. 2001;5:352-6. PMID: 11753254, DOI:10.1067/ mpa.2001.120175

8. Lueder GT, Galli ML. Effect of preoperative stability of alignment on outcome of strabismus surgery for infantile esotropia. J AAPOS. 2008;12:66-8. PMID: 18160320, DOI:10.1016/j. jaapos.2007.09.002

9. Altman HE, Hiatt RL, DeWeese MW. Ocular findings in cerebral palsy. South Med J.1966;59:1015-8. PMID: 5919765

10. Hiles DA, Wallar PH, McFarlane F. Current concepts in the management of strabismus in children with cerebral palsy. Ann Ophthalomol. 1975;7:789-97. PMID: 1147506

11. Sandfeld Nielsen L, Skov L, Jensen H. Visual dysfunctions and ocular disorders in children with developmental delay. II. As- 
pects of refractive errors, strabismus and contrast sensitivity. Acta Ophthalmol Scand. 2007;85(4):419-26. DOI: 10.1111/ j.1600-0420.2007.00881.x

12. Salt A, Sargent J. Common visual problems in children with disability. Arch Dis Child. 2014;99(12):1163-8. DOI:10.1136/ archdischild-2013-305267.

13. Wallace DK, Christiansen SP, Sprunger DT, Melia M, Lee KA, Morse CL, et al. Esotropia and Exotropia Preferred Practice Pattern ${ }^{\circledR}$. Ophthalmology. 2018;125(1):P143-P183. DOI: 10.1016/j.ophtha.2017.10.007.

14. Guidelines for the Management of Strabismus in Childhood. Royal College of Ophthalmologists. March 2012. Available at: https://www.rcophth.ac.uk/wp-content/uploads/2014/12/ 2012-SCI-250-Guidelines-for-Management-of-Strabismusin-Childhood-2012.pdf

15. Na KH, Kim SH. Comparison of clinical features and longterm surgical outcomes in infantile constant and intermittent exotropia. J Pediatr Ophthalmol Strabismus. 2016;53(2):99104. DOI: $10.3928 / 01913913-20160122-05$

16. Christiansen SP, Chandler DL, Holmes JM, Arnold RW, Birch E, Dagi LR, et al.; Pediatric Eye Disease Investigator group. Instability of ocular alignment in childhood esotropia. Ophthalmology. 2008;115(12):2266-74. PMID: 18973948, DOI:10.1016/j.ophtha.2008.08.011

17. Voskresensky V. Konkomitantni strabizam (Concomitant strabismus). In: Čupak K, ed. Oftalmologija (Ophthalmology). $2^{\text {nd }}$ edn. Zagreb: Nakladni zavod Globus, 2004; p. 729-55. (in Croatian)

18. West S, Williams C. Amblyopia in children (aged 7 years or less). BMJ Clin Evid. 2016;2016. pii: 0709.

19. Friedman DS, Repka MX, Katz J, Giordano L, Ibironke J, Hawse $\mathrm{P}$, et al. Prevalence of amblyopia and strabismus in white and African American children aged 6 through to 71 months: the Baltimore Pediatric Eye Disease Study. Ophthalmology. 2009;116:2128-34. PMID: 19762084, DOI:10.1016/j.ophtha.2009.04.034

20. Multi-ethnic Pediatric Eye Disease Study Group. Prevalence of amblyopia and strabismus in African American and Hispanic Children aged 6 to 72 months: the Multi-Ethnic Pediatric Eye Disease Study. Ophthalmology. 2008;115:1229-36. PMID: 17953989, DOI:10.1016/j.ophtha.2007.08.001

21. Karlica D, Galetović D, Znaor L, Bucat M. Strabismus incidence in infants born in Split-Dalmatia County 2002-2005. Acta Clin Croat. 2008;47(1):5-8. PMID: 18714640

22. Hoyt CS. Visual function in the brain-damaged child. Eye. 2003; 17:369-84. PMID: 12724701, DOI:10.1038/sj.eye.6700364

23. Jacobson L, Ygge J, Flodmark O, Ek U. Visual and perceptual characteristics, ocular motility and strabismus in children with periventricular leukomalacia. Strabismus. 2002;23:155-9. PMID: 12221499

24. Choi HY, Jung J. Clinical features and surgical outcome of strabismus in periventricular leukomalacia. Invest Ophthalmol Vis Sci. 2013;54:3640.
25. Drover JR, Stager DR Sr, Morale SE, Leffler JN, Birch EE. Improvement in motor development following surgery for infantile esotropia. J AAPOS. 2008;12:136-40. PMID: 18083593, DOI:10.1016/j.jaapos.2007.08.013

26. Holman RE, Merritt JC. Infantile esotropia: results in the neurologically impaired and 'normal' child at NCMH (six years). J Pediatr Ophthalmol Strabismus. 1986;23(1):41-5. PMID: 3950844

27. Charles SJ, Moore AT. Results of early surgery for infantile esotropia in normal and neurologically impaired infants. Eye. 1992;6:603-6. PMID: 1289137, DOI: 10.1038/eye.1992.130

28. Sekeroglu HT, Turan KE, Arslan U, Sener EC, Sanac AS. Strabismus associated with neurological impairment: retrospective case series. J Clin Case Rep. 2014;4:373. DOI: 10.4172/21657920.1000373

29. Fazzi E, Signorini SG, Bova SM, La Piana R, Ondei P, Bertone $\mathrm{C}$, et al. Spectrum of visual disorders in children with cerebral visual impairment. J Child Neurol. 2007;22(3):294-301. PMID: 17621499, DOI:10.1177/08830738070220030801

30. Nielsen LS, Skov L, Jensen H. Visual dysfunctions and ocular disorders in children with developmental delay. I. Prevalence, diagnoses and aetiology of visual impairment. Acta Ophthalmol Scand. 2007;85(2):149-56. PMID: 17263780, DOI: 10.1111/j.1600-0420.2006.00867.x

31. Can CÜ, Polat S, Yaşar M, İlhan B, Altinaş AGK. Ocular alignment and results of strabismus surgery in neurologically impaired children. Int J Ophthalmol. 2012;5(1):113-5. PMID: 22553767, DOI:10.3980/j.issn.2222-3959.2012.01.23

32. Habot-Wilner Z, Spierer A, Barequet IS, Wygnanski- Jaffe T. Long-term results of esotropia surgery in children with developmental delay. J AAPOS. 2012;16(1):32-5. PMID: 22370662, DOI:10.1016/j.jaapos.2011.10.013

33. Liu G, Ranka MP. Strabismus surgery for children with developmental delay. Curr Opin Ophthalmol. 2014 Sep;25(5): 417-23. doi: 10.1097/ICU.0000000000000086

34. Erkillä H, Lindberg L, Kallio AK. Strabismus in children with cerebral palsy. Acta Ophthalmol Scand. 1996;74(6):636-8. PMID: 9017059

35. Habot-Wilner Z, Spierer A, Glovinsky J, Wygnanski- Jaffe T. Bilateral medial rectus muscle recession: results in children with developmental delay compared with normally developed children. J AAPOS. 2006;10(2):150-4. PMID: 16678750, DOI: 10.1016/j.jaapos.2005.11.013

36. Quoc EB, Milleret C. Origins of strabismus and loss of binocular vision. Front Integr Neurosci. 2014;8:1-19. PMID: 25309358, DOI:10.3389/fnint.2014.00071

37. Volpe JJ. Brain injury in premature infants: a complex amalgam of destructive and developmental disturbances. Lancet Neurol. 2009;8(1):110-24. PMID: 19081519, DOI:10.1016/S14744422(08)70294-1

38. Zehavi-Dorin T, Ben-Zion I, Mezer E, Wygnanski-Jaffe T. Long-term results of bilateral medial rectus muscle recession in children with developmental delay. Strabismus. 2016;24(1): 7-11. DOI: 10.3109/09273972.2015.1130064 


\section{Sažetak \\ PROMJENJIVOST KUTA ŠKILJENJA U PRIJEVREMENO ROĐENE DJECE S NEUROLOŠKIM OŠTEĆENJEM I STRABIZMOM: DVANAESTOGODIŠNJE PRAĆENJE}

\section{E. Sardelici i D. Karlica Utrobicic}

Cilj ovoga retrospektivnog istraživanja bio je odrediti promjenjivost kuta škiljenja i opravdanost kirurškog zahvata u prijevremeno rođene djece s neurološkim oštećenjem i strabizmom tijekom dvanaestogodišnjeg razdoblja praćenja. Istraživanjem je obuhvaćena skupina od jedanaestoro prematurusa rođenih 2003. godine koji su praćeni od 2005. do 2016. godine i liječeni isključivo konzervativno. U sedmero djece je pri prvom mjerenju nađen konvergentni strabizam, dok je četvero preostale djece imalo divergentni strabizam. Kod sve praćene djece zabilježena je značajna korelacija izmjerenog kuta škiljenja s vremenom praćenja, pričem je u djece s početnim konvergentnim strabizmom kut škiljenja postajao manje konvergentan (manje pozitivan) s rastućom dobi djeteta, mijenjao smjer i postajao sve više divergentan (više negativan). $U$ djece s početnim divergentnim strabizmom kut škiljenja bio je sve manje divergentan (manje negativan) u odnosu na rastuću dob djeteta, mijenjao smjer i postajao sve više konvergentan (više pozitivan). Tijekom dvanaest godina praćenja utvrđena je značajna razlika u medijanima kuta škiljenja. Zbog promjenjivosti kuta škiljenja nije se moglo utvrditi optimalno vrijeme ni opravdanost operacijskog zahvata u korekciji strabizma prijevremeno rođene, neurološki oštećene djece.

Ključne riječi: Strabizam; Nedonošče; Razvojni poreméaji 